EXPERIMENTAL STUDY

\title{
Regulation of ghrelin secretion by somatostatin analogs in rats
}

\author{
Antonio P Silva, Kerstin Bethmann, Friedrich Raulf and Herbert A Schmid
}

Novartis Institutes for Biomedical Research, Basel, Switzerland

(Correspondence should be addressed to H Schmid; Email: herbert.schmid@novartis.com)

\begin{abstract}
Objective: Ghrelin is a hormone present in the plasma in two forms: octanoylated and des-octanoylated ghrelin. In pathophysiological conditions such as Prader-Willi syndrome and ghrelinoma, elevated ghrelin plasma levels are associated with pathological obesity. Clinical studies have shown that somatostatin downregulates ghrelin plasma levels in healthy volunteers. The aim of this study was to investigate the effects of two somatostatin analogues, SOM230 and octreotide, on ghrelin secretion in rats.

Methods: Ghrelin secretion was either unstimulated or stimulated by overnight fasting. Treatment with SOM230 and octreotide was either acute (s.c. injection $1 \mathrm{~h}$ before blood sampling) or prolonged (continuous s.c. infusion via 14-day osmotic minipumps).

Results: Acute treatment with octreotide dose-dependently inhibited unstimulated and stimulated secretion of total and active ghrelin. SOM230 $(30 \mu \mathrm{g} / \mathrm{kg})$ inhibited active ghrelin in fasted rats. Lower doses had no effect. After 7 days of treatment, active ghrelin was strongly inhibited by both compounds in fasted animals, with a stronger effect for octreotide. Lower inhibition was achieved in fed rats. After 14 days, the inhibition with octreotide in fasted rats was lower and SOM230 had no effect. Somatostatin receptor expression analysis in the rat glandular stomach revealed a predominant $\mathrm{sst}_{1}$ and $\mathrm{sst}_{2}$ expression, low expression of $\mathrm{sst}_{3}$ and $\mathrm{sst}_{4}$, and hardly detectable $\mathrm{sst}_{5}$ mRNA expression.

Conclusions: Somatostatin analogues may be useful for the inhibition of physiologically elevated ghrelin plasma levels. This inhibition appears to be mediated by $s t_{2}$ receptors in the rat, and desensitizes after 14 days of treatment.
\end{abstract}

European Journal of Endocrinology 152 887-894

\section{Introduction}

Ghrelin is a 28-amino-acid peptide identified in 1999 and produced mainly in the stomach (1). It is the endogenous ligand for the growth hormone secretagogue receptors (GHS-Rs). Beside its growth hormone (GH)-releasing activity, ghrelin exerts additional effects, such as increased food intake and adiposity, stimulation of stomach motility and secretion, inhibition of insulin secretion, and cardioprotective effects. These effects are mediated by the receptor GHS-R1a, and exerted by acylated ghrelin (also called active ghrelin, octanoylated on $\mathrm{Ser}^{3}$ ) (2). Des-octanoyl-ghrelin also has biological activity; indeed, antiproliferative effects on the human breast carcinoma cell line MCF-7 have been reported (3). The regulation of energy balance by ghrelin is controlled by the modulation of ghrelin plasma levels, which are upregulated by fasting, hypoglycemia, and leptin, and downregulated by food intake, hyperglycemia, and obesity (4-9).
In pathophysiological conditions, such as Prader-Willi syndrome (PWS) and ghrelinoma, elevated plasma levels of ghrelin are reported (10-13). PWS is a genetic disorder affecting 1 in 15000 children. The main features of the syndrome are infantile hypotonia, mental deficiency, hypogonadism, and obesity associated with uncontrollable and voracious appetite (14). Whether the high levels of ghrelin reported in these patients are responsible for the obese phenotype is not established clearly. However, the orexigenic effect of ghrelin has been clearly established in humans $(15,16)$. Recent publications have shown the production of ghrelin in endocrine tumors of the gastrointestinal tract $(13,17$, 18). In these studies, the elevated plasma levels of ghrelin observed in patients presenting with ghrelinoma coincided with a high body mass index $\left(\geq 30 \mathrm{~kg} / \mathrm{m}^{2}\right)$. Ghrelin secretion can be regulated by different mediators including leptin, estrogens, insulin, glucose, acetylcholine, and somatostatin $(2,5,19)$. In human 
healthy volunteers, somatostatin was shown to downregulate elevated plasma levels of ghrelin in subjects fasted for 12 or $36 \mathrm{~h}(20,21)$. Somatostatin is a 14or 28-amino-acid peptide involved in the regulation of hormone and growth factor secretion in various organs. Currently available somatostatin analogues (octreotide and lanreotide) are used for the treatment of two major indications, i.e. acromegaly and carcinoid syndrome associated with gastro-entero-pancreatic tumors. Since some $50 \%$ of gastro-entero-pancreatic tumor patients show an escape of response after 1 year of treatment and $35 \%$ of acromegalic patients do not or only partially respond to treatment with these sst $_{2}$-preferring agonists $(22,23)$, a new somatostatin analogue with a wider affinity profile for sst receptors was developed. SOM230 is a cyclohexapeptide able to bind $\mathrm{sst}_{1}, \mathrm{sst}_{2}, \mathrm{sst}_{3}$, and $\mathrm{sst}_{5}$ receptors with high affinity (24). This novel multiligand compound shows a 30- and 40-fold higher affinity to sst $_{1}$ and sst $_{5}$, respectively, and has a 3-fold lower affinity to sst $_{2}$ compared with octretide. SOM230 is very effective in lowering GH secretion from the pituitary in vitro as well as in vivo. Insulin-like growth factor I (IGF-I) secretion is also decreased strongly by SOM230 in rats (25). Due to its prolonged terminal elimination half-life $(23 \mathrm{~h}$ in rats, $11 \mathrm{~h}$ in humans), SOM230 has a very long duration of action compared with octreotide (25). Furthermore, the escape of response observed for the control of IGF-I secretion on treatment with octreotide is not observed with SOM230 in rats (26). The aim of this study was to determine the comparative effects of octreotide and SOM230 on the secretion of both total ghrelin and active ghrelin in rats either fasted overnight or fed ad libitum.

\section{Materials and methods}

The experiments described in this article were performed according to national animal welfare requirements (Eidgenossische Tierversuchsbewilligung, Switzerland).

\section{Compounds and formulation}

For acute $(1 \mathrm{~h})$ treatment by s.c. injection, SOM230 acetate was dissolved in sterile water and stocks stored frozen in $100 \times$ concentrations. On the day of experiment, the stock solutions were diluted with $0.9 \%$ sterile saline to the final concentration $(\mathrm{pH}$ 5-6). SMS 201-995 acetate (octreotide) was prepared in the same way as SOM230. For the long-term (14 days) treatment, SOM230 and octreotide were dissolved in sterile saline and put in Alzet osmotic 14-day minipumps delivering SOM230 or octreotide at a dose of 3,10 , or $30 \mu \mathrm{g} / \mathrm{kg}$ per $\mathrm{h}$.

\section{Animals and treatments}

Adult male Lewis rats (LEW/Han/Hsd, Harlan, The Netherlands), 236-298 g, were housed three per cage under controlled light (12 h light/12 h dark) and temperature $\left(22^{\circ} \mathrm{C}\right)$. The rats had water and chow food ad libitum unless otherwise stated. Animals were weighed on the day of blood sampling, and on the day of minipump insertion for the long-term-treatment experiments. For the 1-h treatment experiment all animals, except those of the fed groups, were fasted at $1500 \mathrm{~h}$ on the day before the experiment. On the day of experiment, SOM230 or octreotide was injected s.c., $1 \mathrm{ml} / \mathrm{kg}$, at a dose of 3,10 , or $30 \mu \mathrm{g} / \mathrm{kg}$. After $1 \mathrm{~h}$, animals were anesthetized with $5 \%$ isoflurane (Forene; Abbott AG, Baar, Switzerland), and total blood was taken from the abdominal aorta. For the 14-day treatment experiment, minipumps containing either $0.9 \% \mathrm{NaCl}$, SOM 230 or octreotide were inserted s.c. on day 0 . On days 6 and 13, animals (except those in the fed groups) were fasted at $1500 \mathrm{~h}$. On day 7, after anesthesia with $5 \%$ isoflurane, total blood was taken from the sublingual vein. On day 14, after anesthesia with $5 \%$ isoflurane, total blood was taken from the abdominal aorta. For ghrelin (total and active), blood was taken on EDTA and aprotinin $(100 \mathrm{U} / \mathrm{ml})$. Plasma was separated by centrifugation at 3000 r.p.m. for $10 \mathrm{~min}$ at $4{ }^{\circ} \mathrm{C}$, and aliquoted in different tubes for total and active ghrelin. For the determination of active ghrelin, plasma was acidified with $10 \mu \mathrm{l} \mathrm{HCl}$ $(1 \mathrm{M}) / 100 \mu \mathrm{l}$ plasma to avoid hydrolysis of the octanoyl group of active ghrelin.

\section{Determination of total and active ghrelin}

Plasma levels of total and active ghrelin were determined by RIA, using commercially available kits (Linco Research, St Charles, MI, USA; catalogue nos GHRT89HK and GHRA88HK, respectively).

\section{Somatostatin receptor expression analysis}

Lewis rats (LEW/Han/Hsd; five per group) were either fed ad libitum or fasted overnight. On the day of experiment, they were anesthetized with 5\% isoflurane, and killed with an overdose of pentobarbital (Vetanarcol; Veterinaria AG, Zurich, Switzerland). The stomach was excised, opened longitudinally, and a biopsy of the glandular part of the stomach was snap-frozen in liquid nitrogen and stored at $-80^{\circ} \mathrm{C}$. Frozen samples were incubated for at least $18 \mathrm{~h}$ at $-20^{\circ} \mathrm{C}$ in RNAlater-ICE (Ambion, Austin, TX, USA). Tissue disruption and homogenization was performed in guanidine thiocyanate containing lysis buffer (RLT buffer, RNeasy minikit; Qiagen, Basel, Switzerland) using a BioPulverizer Green tube (BIO 101, Carlsbad, CA, USA). Total RNA was then extracted using the RNeasy minikit according to manufacturer's instructions, including a 
digestion with DNase to minimize contamination with genomic DNA. $1 \mu \mathrm{g}$ total RNA was reverse transcribed using the superscript III reverse transcriptase (Invitrogen, Basel, Switzerland) and random hexamer primers (Roche Diagnostics, Basel, Switzerland). The resulting cDNA (amount equivalent to $10 \mathrm{ng}$ total RNA) was submitted to quantitative real-time PCR for the following targets: $\mathrm{sst}_{1}, \mathrm{sst}_{2}, \mathrm{sst}_{3}, \mathrm{sst}_{4}, \mathrm{sst}_{5}$, and $18 \mathrm{~S}$ rRNA. The primers and probes for somatostatin and sst $_{2}$ were provided as TaqMan assays-on-demand (Applied Biosystems, Foster City, CA, USA; catalogue nos Rn_00561967_m1 and Rn_00571116_m1, respectively). Primers and probe for $\mathrm{sst}_{1}, \mathrm{sst}_{3}, \mathrm{sst}_{4}$, and $\mathrm{sst}_{5}$ were provided as assays-by-design (Applied Biosystems).

The sequences for TaqMan primers and probes were as follows. sst $_{1}$, forward primer, 5'-AGA GCG GCT ACC AGA CTG T-3'; reverse primer, 5'-GGA GCT GGG CTT ACT TGA CA-3'; probe, 5'-CCA GTT ACC GCT CCC C-3'; sst $_{3}$, forward primer, 5'-GTC CCC TTC CAC CTT TGC A-3'; reverse primer, 5'-GAG GAT CAG TCA GCA GCA ACT AG-3'; probe, 5'-CAA CCC CGT AAG GTT TG-3'; sst $_{4}$, forward primer, 5'-GGA TCG CTA TGT GGC TGT AGT G-3'; reverse primer, 5'-GGC CGC CGG TAG GT-3'; probe, 5'-CCC TCT GCG AGC TGC-3'; sst $_{5}$, forward primer, 5'-CGG CTT TCT CTC GGA CAA CT-3'; reverse primer, 5'-CTC TAC GTA GGC ACA GAA CCT T-3'; probe, 5'-TCC GCC AGA GCT TC-3'. For $18 \mathrm{~S}$ rRNA evaluation, the TaqMan rRNA control reagents (Applied Biosystems; catalogue no. 4308329) were used according to the manufacturer's instructions. Data were analyzed using the relative standard-curve method, and results are expressed as relative expression normalized to $18 \mathrm{~S}$ rRNA expression.

\section{Statistical analysis}

Data were compared between groups using unpaired $t$-tests.

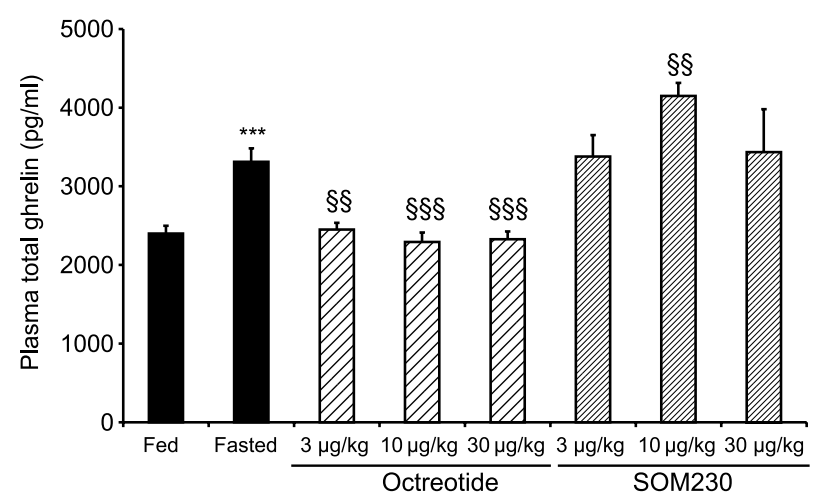

\section{Results}

\section{Acute effect of SOM230 and octreotide}

The levels of total and active ghrelin measured in fed animals were $2400 \pm 98$ and $577 \pm 41 \mathrm{pg} / \mathrm{ml}$, respectively. In order to increase the plasma levels of ghrelin, rats were fasted overnight. In fasted animals, the plasma concentrations of ghrelin reached the values of $3312 \pm 170 \mathrm{pg} / \mathrm{ml}$ for total ghrelin and $749 \pm 33 \mathrm{pg} / \mathrm{ml}$ for active ghrelin (Figs $1 \mathrm{~A}$ and $2 \mathrm{~A}$ ). In both groups, the amount of active ghrelin represented about $20 \%$ of the amount of total ghrelin $(24.0 \pm 1.0 \%$ in fed animals and $22.7 \pm 1.1 \%$ in fasted in animals). In the treated groups, $1 \mathrm{~h}$ after s.c. injection of octreotide at 3,10 , or $30 \mu \mathrm{g} / \mathrm{kg}$, the level of total ghrelin dropped down to the levels observed in fed animals (2451 \pm 86 , $2293 \pm 120$, and $2327 \pm 100 \mathrm{pg} / \mathrm{ml}$, respectively; Fig. 1A). Stronger inhibition was observed on the level of active ghrelin, with levels below those observed in fed animals after treatment with octreotide 10 and $30 \mu \mathrm{g} / \mathrm{kg} \quad(445 \pm 33 \mathrm{pg} / \mathrm{ml}, P=0.02 ; 415 \pm 31 \mathrm{pg} / \mathrm{ml}$, $P=0.008$, respectively; Fig. 2A). When rats were fed ad libitum, a dose-dependent inhibition of total and active ghrelin secretion by octreotide was observed (Figs $1 \mathrm{~B}$ and 2B), with levels significantly lower than in the non-treated group at doses of 10 and $30 \mu \mathrm{g} / \mathrm{kg}$ $(1400 \pm 114$ and $1030 \pm 133 \mathrm{pg} / \mathrm{ml}$ respectively for total ghrelin, and $371 \pm 28$ and $274 \pm 27 \mathrm{pg} / \mathrm{ml}$ respectively for active ghrelin). SOM230 had no effect on total ghrelin at 3 or $30 \mu \mathrm{g} / \mathrm{kg}$ (Fig. 1) but, at $10 \mu \mathrm{g} / \mathrm{kg}$, a small but significant increase in plasma ghrelin was observed in fasted rats $(4148 \pm 166$ versus $3312 \pm 170 \mathrm{pg} / \mathrm{ml}, \quad P=0.0032)$ and in fed rats $(2249 \pm 122$ versus $1770 \pm 108 \mathrm{pg} / \mathrm{ml}, P=0.0093)$. Similarly, no effect of SOM230 on active ghrelin levels was observed at $3 \mu \mathrm{g} / \mathrm{kg}$ (Fig. 2). A tendency to further stimulate active ghrelin was observed at $10 \mu \mathrm{g} / \mathrm{kg}$ in fasted animals only. At $30 \mu \mathrm{g} / \mathrm{kg}$, SOM230 inhibited active ghrelin secretion significantly in fasted rats

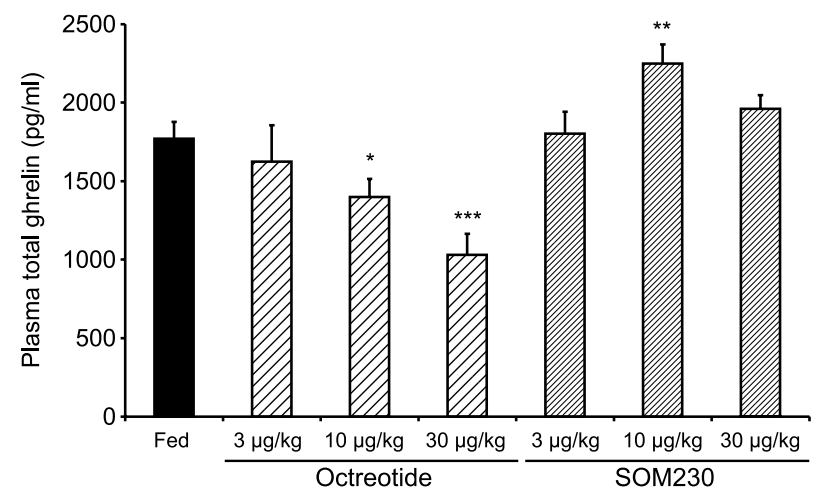

Figure 1 Acute effect of SOM230 and octreotide on (A) fasting-induced total ghrelin secretion and (B) total ghrelin secretion in fed rats. Rat total ghrelin plasma levels as determined by RIA are expressed as mean \pm S.E.M.; $n=6$ animals per group. Rats were fed ad libitum or fasted overnight, and SOM230 and octreotide were injected s.c. $1 \mathrm{~h}$ before blood sampling. ${ }^{\star} P<0.05,{ }^{\star \star} P<0.01,{ }^{\star \star \star} P<0.001 \mathrm{com}$ pared with the fed group. $\S \S P<0.01, \S \S \S P<0.001$ compared with the fasted group. 



Figure 2 Acute effect of SOM230 and octreotide on (A) fasting-induced active ghrelin secretion and (B) active ghrelin secretion in fed rats. Rat active ghrelin plasma levels as determined by RIA are expressed as mean \pm S.E.M.; $n=6$ animals per group. Rats were fed ad libitum or fasted overnight, and SOM230 and octreotide were injected s.c. $1 \mathrm{~h}$ before blood sampling. ${ }^{\star \star} P<0.01,{ }^{\star \star \star} P<0.001$ compared with the fed group. $\S P<0.05, \S \S P<0.01$, $\S \S P<0.001$ compared with the fasted group.

(589 50 versus $749 \pm 33 \mathrm{pg} / \mathrm{ml}, P=0.017$; Fig. 2 A), but not in fed rats (Fig. 2B).

\section{Effects of prolonged treatment with SOM230 and octreotide}

Rats treated for 14 days with SOM230 or octreotide had a body weight lower than rats receiving $0.9 \%$ $\mathrm{NaCl}$, thus confirming previous data (26) and the efficiency of the compound infusion (Fig. 3). After 7 and 14 days of treatment, octreotide significantly inhibited total ghrelin increase induced by overnight fasting, as well as total ghrelin levels in fed rats (Fig. 4). In contrast, SOM230 had no effect on total ghrelin levels after 7 and 14 days of treatment at any dose. After 7 days of treatment, fasting-induced active ghrelin levels were inhibited strongly (below levels of fed rats) by both octreotide and SOM230, with a stronger effect observed with octreotide (Fig. 5A, left-hand panel).
After 14 days, loss of response was observed for both compounds. Complete loss of inhibitory effect was observed for SOM230, and partial loss for octreotide, with levels of active ghrelin still reduced to the levels observed (Fig. 5A, right-hand panel). In fed rats, after 7 days, octreotide inhibited active ghrelin secretion $(647 \pm 54 \mathrm{pg} / \mathrm{ml}$ for vehicle-treated rats, and $283 \pm 67 \mathrm{pg} / \mathrm{ml}, P=0.001 ; 482 \pm 70 \mathrm{pg} / \mathrm{ml}, P=0.07$; $359 \pm 44 \mathrm{pg} / \mathrm{ml}, P=0.0012$ at 3,10 , and $30 \mu \mathrm{g} / \mathrm{kg}$ per h, respectively), and SOM230 also inhibited active ghrelin secretion at $30 \mu \mathrm{g} / \mathrm{kg}$ per h $(440 \pm 47 \mathrm{pg} / \mathrm{ml}$, $P=0.01$ ). After 14 days, the inhibitory effect of both compounds was reduced (Fig. 5B). The expression of somatostatin precursor mRNA and sst receptor mRNAs was measured by real-time reverse transcriptase PCR in biopsies of glandular stomach from fed or overnight fasted rats. A predominant expression of sst $_{2}$ and sst $_{1}$ was measured in the rat glandular stomach. sst $_{3}$ and sst $_{4}$ mRNAs were also expressed in
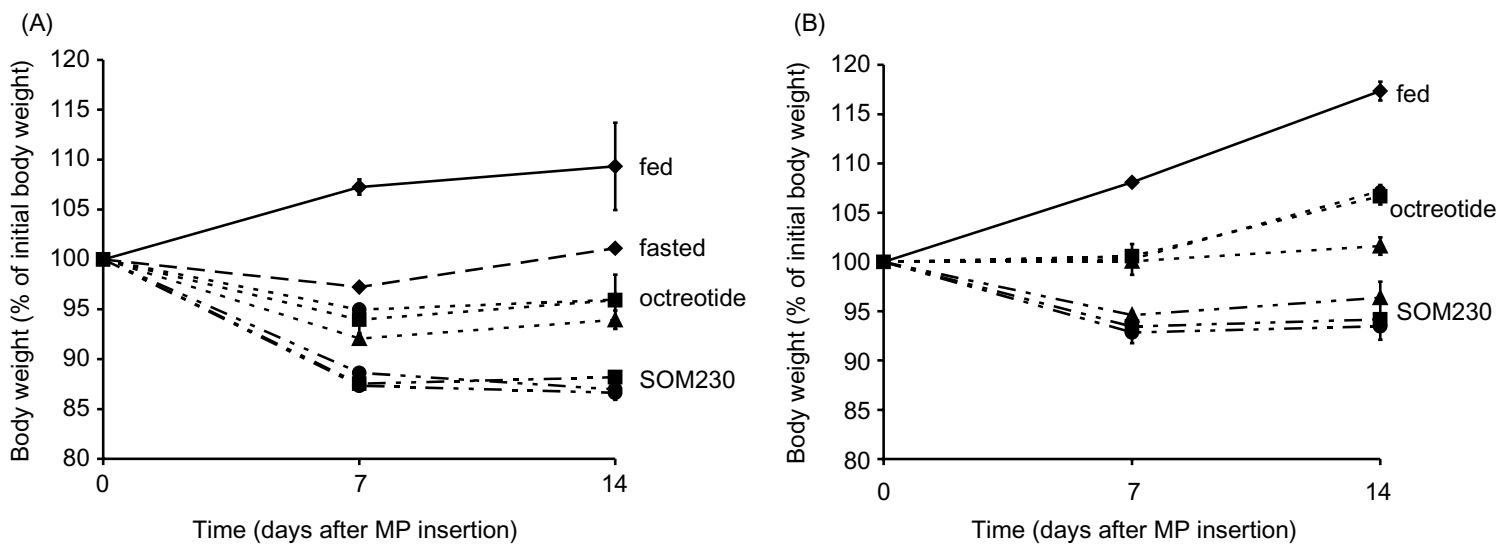

Figure 3 Change in rat body weight 7 and 14 days after s.c. implantation of osmotic minipumps (MP). Rats were either fasted (A) or fed ad libitum (B). Results are expressed as mean \pm S.E.M. of the percentage of initial body weight; $n=6$ rats per group. line, fed rats; $\bullet$ with dashed line, fasted rats; $\bullet$ with dashed line, octreotide $3 \mu \mathrm{g} / \mathrm{kg} \mathrm{per} \mathrm{h;} \boldsymbol{\Delta}$ with dashed line, octreotide $10 \mu \mathrm{g} / \mathrm{kg}$ per $\mathrm{h}$; with dashed line, octreotide $30 \mu \mathrm{g} / \mathrm{kg}$ per h; $\bullet$ with long/short-dashed line, SOM230 $3 \mu \mathrm{g} / \mathrm{kg}$ per h; $\boldsymbol{\Delta}$ with long/short-dashed line, SOM230 $10 \mu \mathrm{g} / \mathrm{kg}$ per h; with long/short-dashed line, SOM230 $30 \mu \mathrm{g} / \mathrm{kg}$ per h. 

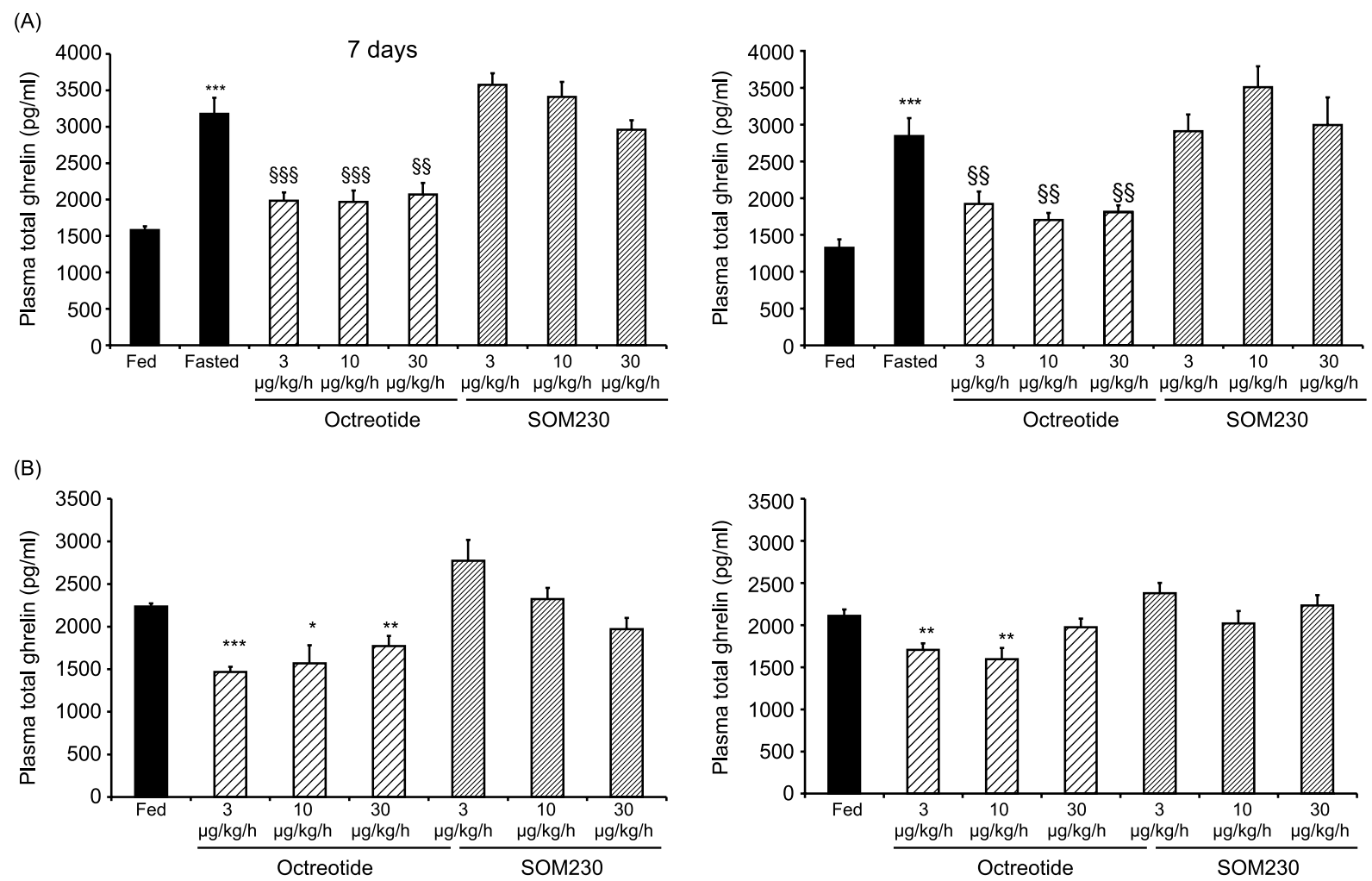

Figure 4 Effect of SOM230 and octreotide on total ghrelin secretion after 7 and 14 days of treatment. Rats were either (A) fasted overnight or (B) fed ad libitum. Rat total ghrelin plasma levels as determined by RIA on days 7 (left-hand panels) and 14 (right-hand panels) are expressed as mean \pm S.E.M.; $n=6$ animals per group. ${ }^{\star} P<0.05,{ }^{*} P<0.01,{ }^{* \star *} P<0.001$ compared with the fed group. $\S \S P<0.01, \S \S \S P<0.001$ compared with the fasted group.

lower amounts, and sst ${ }_{5}$ mRNA was barely detectable in the rat glandular stomach (Fig. 6). sst $_{2}$ receptor expression was lower in fasted compared with fed animals (relative expression of $2.23 \pm 0.09 \mathrm{pg} / \mathrm{ml}$ in fed rats compared to $1.13 \pm 0.33 \mathrm{pg} / \mathrm{ml}$ in fasted rats, $P=0.018$ ), in contrast to $\mathrm{sst}_{1}, \mathrm{sst}_{3}$, and $\mathrm{sst}_{4}$. Somatostatin precursor mRNA was also expressed in significant amounts in the rat glandular stomach. Its expression was not affected by overnight fasting.

\section{Discussion}

This study shows the dose-dependent inhibition of ghrelin secretion achieved $1 \mathrm{~h}$ following injection of octreotide at 3,10 , and $30 \mu \mathrm{g} / \mathrm{kg}$, both in fed rats and after stimulation of secretion by overnight fasting. With SOM230, significant acute inhibition of active ghrelin was observed at $30 \mu \mathrm{g} / \mathrm{kg}$ in fasted rats only. After 7 days of treatment, active ghrelin was strongly inhibited by both octreotide and SOM230 in fasted rats, with a stronger effect for octreotide. This inhibition of active ghrelin secretion after 7 days was less pronounced in fed rats. After 14 days, desensitization of this effect was observed, leading to lower inhibition with octreotide and absence of inhibition with SOM230 in fasted rats, and absence of inhibition for both compounds in fed rats. Since food intake is stimulated by the octanoylated form of ghrelin (2), those data obtained for active ghrelin modulation are the more physiologically relevant. sst receptor expression analysis in the rat glandular stomach showed a predominant expression of $\mathrm{sst}_{1}$ and $\mathrm{sst}_{2}$, lower $\mathrm{sst}_{3}$ and $\mathrm{sst}_{4}$, and barely detectable sst ${ }_{5} \mathrm{mRNA}$ expression. These data suggest that inhibition of ghrelin secretion might be mediated by $\mathrm{sst}_{1}, \mathrm{sst}_{2}$, or $\mathrm{sst}_{3}$ receptors. The involvement of $s t_{4}$ and $s t_{5}$ receptors can be excluded because both compounds tested have no activity at the $\mathrm{sst}_{4}$ receptor, and $\mathrm{sst}_{5}$ receptor is not expressed in the target tissue. The affinity of octreotide for sst $_{2}$ receptors is about 3-fold higher compared with SOM230, with $\mathrm{IC}_{50}$ values of 0.38 and $1.0 \mathrm{nM}$, respectively (25). In contrast, the affinity of SOM230 for sst $_{1}$ and sst $_{3}$ receptors is higher compared with octreotide $(9.3$ and $1.5 \mathrm{nM}$ versus 280 and $7.1 \mathrm{nM}$, respectively (25)), thus excluding sst $_{1}$ and $\mathrm{sst}_{3}$ as predominant mediators of the inhibition of ghrelin secretion in rats. Recent functional data obtained with cells expressing human recombinant sst receptors showed a 6-fold higher functional activity of octreotide compared with SOM230 on sst $_{2}$ receptors in terms of inhibition of forskolin-induced cAMP 

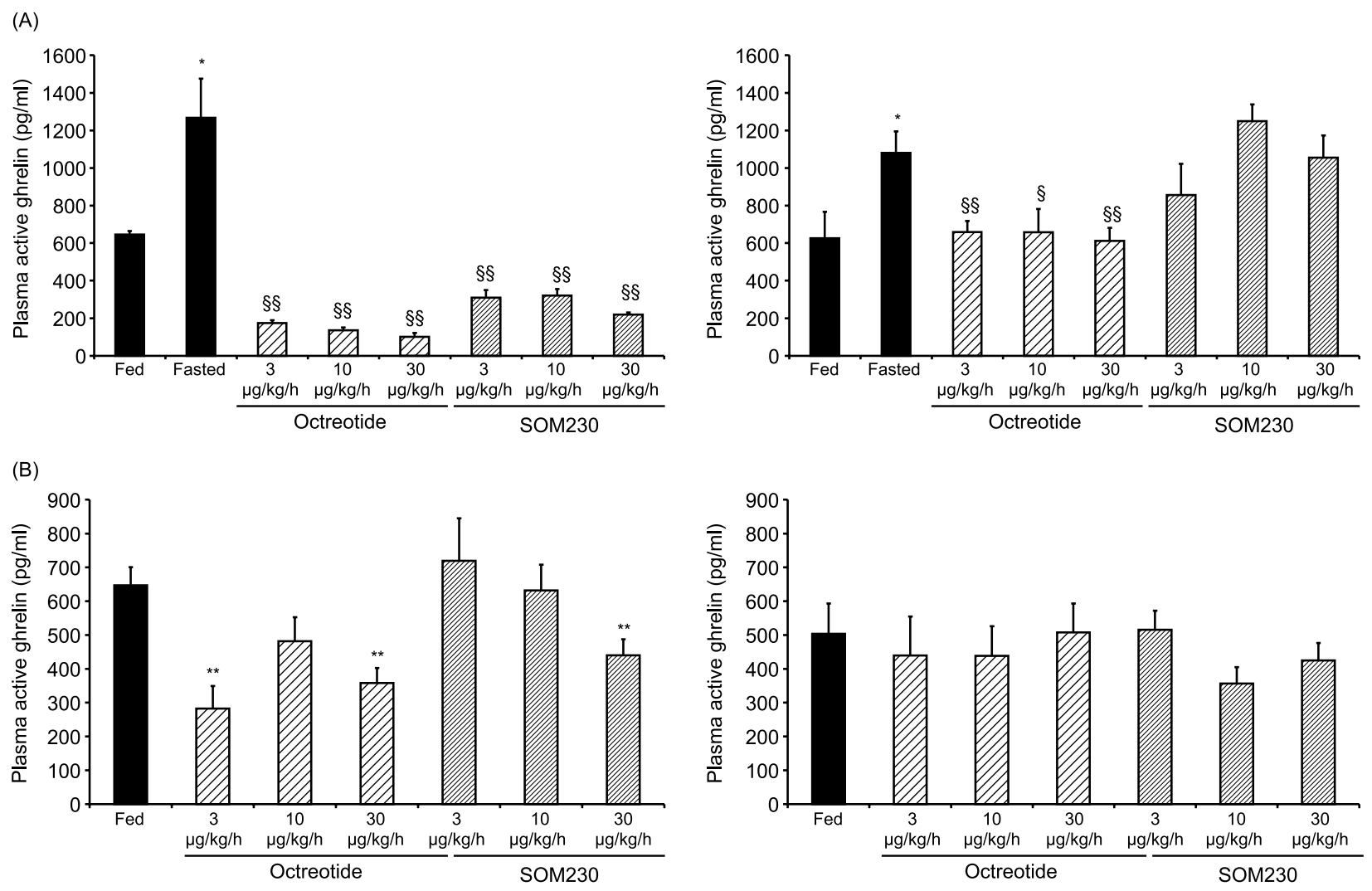

Figure 5 Effect of SOM230 and octreotide on active ghrelin secretion after 7 and 14 days of treatment. Rats were either (A) fasted overnight or (B) fed ad libitum. Rat active ghrelin plasma levels as determined by RIA on days 7 (left-hand panels) and 14 (right-hand panels) are expressed as mean \pm S.E.M.; $n=6$ animals per group. ${ }^{\star} P<0.05$, ${ }^{\star \star} P<0.01$ compared with the fed group. $\S P<0.05$, $\S \S P<0.01$ compared with the fasted group.

accumulation (27). This difference of efficacy is in line with the differences observed for the inhibition of active ghrelin secretion by octreotide and SOM230. Therefore, the $\mathrm{sst}_{2}$ receptor is the most relevant mediator of the inhibition of ghrelin secretion by octreotide and SOM230 in rats.

After 14 days of continuous treatment the inhibitory effect of SOM230 and octreotide declined. Desensitization was previously observed for the regulation of GH/IGF-I secretion by octreotide (26). Inhibition of the GH/IGF-I axis by somatostatin is a sst $_{2}$ - $^{-}$sst $_{5^{-}}$ mediated effect (28), and stronger desensitization was observed with the sst $_{2}$-preferring analogue octreotide compared with the multireceptor ligand SOM230 (26). Therefore, the similarity of the desensitization observed with octreotide and SOM 230 on active ghrelin secretion and the difference observed on GH and IGF-1 secretion further argue for a predominantly or exclusively sst $_{2}$-mediated regulation of ghrelin plasma levels in the rat.
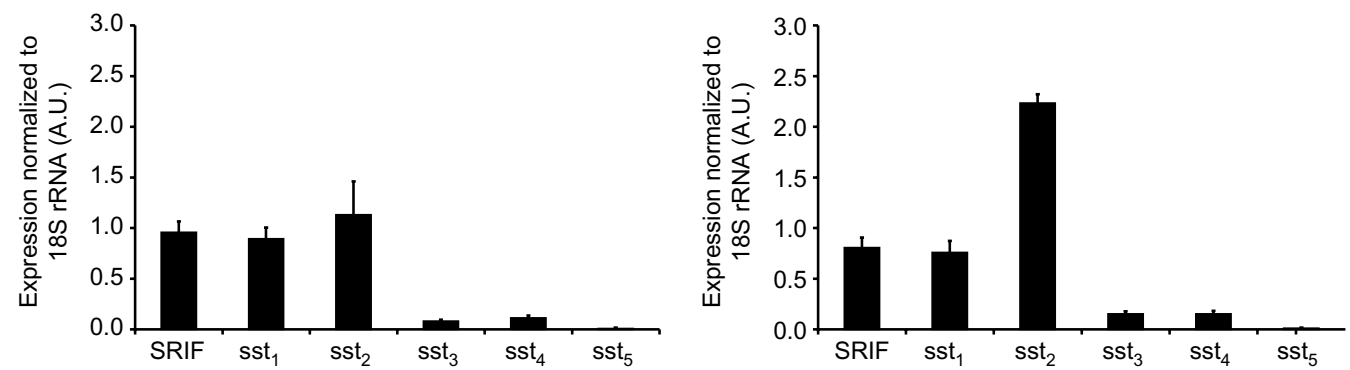

Figure 6 Expression of somatostatin (SRIF) and sst receptor subtype mRNAs in the glandular stomach of overnight fasted rats (lefthand panel) and fed rats (right-hand panel) was determined by quantitative reverse transcriptase PCR. Results are expressed as mean \pm S.E.M. from target mRNA expression normalized to $18 \mathrm{~S}$ rRNA expression, in arbitrary units (A.U.); $n=5$ rats per group. 
Somatostatin receptor expression analysis showed downregulation of $\mathrm{sst}_{2}$ receptors in the rat glandular stomach after overnight fasting. Although the present data do not show an effect of fasting on somatostatin precursor mRNA expression, the downregulation of $\mathrm{sst}_{2}$ mRNA expression might be explained by an increased somatostatin peptide content in the rat glandular stomach. Indeed, various studies have shown that somatostatin concentration in the antral stomach of the rat is increased after fasting (29-31). In a study by Roca et al. (31), increased somatostatin concentration was associated with a decreased number of somatostatin binding sites in the antral mucosa.

In the acute-treatment experiments, after $1 \mathrm{~h}$, a further increase in total ghrelin plasma levels (and a trend to increase in active ghrelin) was observed in the groups treated with $10 \mu \mathrm{g} / \mathrm{kg}$ SOM230. At $30 \mu \mathrm{g} / \mathrm{kg}$ SOM230, the expected inhibition of active ghrelin was observed in fasted rats. The unexpected increase in ghrelin observed with $10 \mu \mathrm{g} / \mathrm{kg}$ SOM230 might be explained by the difference in binding affinities between SOM230 and octreotide on $\mathrm{sst}_{2}$ and $\mathrm{sst}_{5}$ receptors, resulting in different effects on hormone secretion. In binding experiments octreotide has a 16-fold higher affinity for $\mathrm{sst}_{2}$ compared with sst ${ }_{5}$ receptors. In contrast, SOM230 has

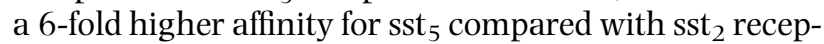
tors. According to our study, sst $_{5}$ receptor is hardly expressed in the stomach, i.e. the main source of ghrelin secretion, in contrast to insulin secreting $\beta$-cells of the pancreas (32). The predominant expression of sst $_{5}$ receptors on $\beta$-cells is the histological correlate for the 11 -foldstronger inhibitory effect of SOM230 on insulin secretion compared with octreotide (25). Several studies have shown that circulating insulin has an inhibitory effect on ghrelin secretion (33-35). Therefore, by inhibiting insulin secretion via the activation of sst $_{5}$ receptors in the pancreas, SOM230 at $10 \mu \mathrm{g} / \mathrm{kg}$ could disinhibit the inhibitory effect of insulin on ghrelin secretion, leading to a further increase in ghrelin. At $30 \mu \mathrm{g} / \mathrm{kg}$ the concentration of SOM230 could be high enough to directly inhibit ghrelin secretion from the stomach via the stimulation of $\mathrm{sst}_{2}$ receptors, and thereby overcome the indirect effect caused by the sst $_{5}$-mediated inhibition of insulin. The stronger inhibitory effect of octreotide on ghrelin secretion can be explained by the 6-fold-higher affinity for and the 6-fold-higher functional activity at sst $_{2}$ receptors compared with SOM230 (27).

Our data are in line with previously published ex vivo data showing that somatostatin and octreotide at nanomolar concentrations inhibited total ghrelin secretion from the perfused rat stomach (36). The inhibition of ghrelin secretion by octreotide has also been shown in a study on nine young healthy male volunteers, with plasma ghrelin concentrations representing almost $50 \%$ of the values obtained under saline infusion (37). In acromegalic patients treated with octreotide, a significant decrease in plasma ghrelin levels was observed (20). The decrease in human plasma levels of ghrelin was observed after 3-9 months of treatment with octreotide. This suggests that, in humans, the inhibitory effect of octreotide on ghrelin secretion is long lasting with slower desensitization than that observed in our study in the rat. A more recent study investigating the effect of somatostatin i.v. infusion in PWS patients showed that somatostatin can also reduce the levels of plasma ghrelin in these patients, although it did not change food intake measured as the quantity of food taken during a period of $1 \mathrm{~h}(38)$.

In summary, the present study indicates that somatostatin analogues may be useful for the inhibition of stimulated and unstimulated ghrelin plasma levels. In the rat, this appears to be mediated primarily or exclusively by the $\mathrm{sst}_{2}$ receptor. In rats rapid desensitization is seen after 14 days, in contrast to the observations made by others in humans. These observations suggest that other somatostatin receptors besides $\mathrm{sst}_{2}$ might be more relevant for the inhibitory effect on ghrelin secretion in humans compared with rats, with potential implications for multireceptor ligands such as SOM230.

\section{Acknowledgements}

We are thankful to Ramona Rebmann for her skillful technical assistance. We also would like to thank Dr Christian Bruns and Professor Gisbert Weckbecker for their support, as well as Gérard Vogt, Cyril Allard, and Corinne Delucis-Bronn for their technical advice.

\section{References}

1 Kojima M, Hosoda H, Date Y, Nakazato M, Matsuo H \& Kangawa K. Ghrelin is a growth-hormone-releasing acylated peptide from stomach. Nature $1999 \mathbf{4 0 2}$ 656-660.

2 De Ambrogi M, Volpe S \& Tamanini C. Ghrelin: central and peripheral effects of a novel peptidyl hormone. Medical Science Monitor 20039 RA217-RA224.

3 Cassoni P, Papotti M, Ghe C, Catapano F, Sapino A, Graziani A, Deghenghi R, Reissmann T, Ghigo E \& Muccioli G. Identification, characterization, and biological activity of specific receptors for natural (ghrelin) and synthetic growth hormone secretagogues and analogs in human breast carcinomas and cell lines. Journal of Clinical Endocrinology and Metabolism 200186 1738-1745.

4 Toshinai K, Mondal MS, Nakazato M, Date Y, Murakami N, Kojima M, Kangawa K \& Matsukura S. Upregulation of Ghrelin expression in the stomach upon fasting, insulin-induced hypoglycemia, and leptin administration. Biochemical Biophysical Research Communications 2001281 1220-1225.

5 Ariyasu H, Takaya K, Hosoda H, Iwakura H, Ebihara K, Mori K, Ogawa Y, Hosoda K, Akamizu T, Kojima M, Kangawa K \& Nakao K. Delayed short-term secretory regulation of ghrelin in obese animals: evidenced by a specific RIA for the active form of ghrelin. Endocrinology $20021433341-3350$.

6 Tschop M, Smiley DL \& Heiman ML. Ghrelin induces adiposity in rodents. Nature $2000 \mathbf{4 0 7} 908-913$.

7 Horvath TL, Diano S, Sotonyi P, Heiman M \& Tschop M. Minireview: ghrelin and the regulation of energy balance-a hypothalamic perspective. Endocrinology $20011424163-4169$.

8 Soriano-Guillen L, Barrios V, Campos-Barros A \& Argente J. Ghrelin levels in obesity and anorexia nervosa: effect of weight reduction or recuperation. The Journal of Pediatrics $2004 \mathbf{1 4 4}$ $36-42$. 
9 Marzullo P, Verti B, Savia G, Walker GE, Guzzaloni G, Tagliaferri M, Di Blasio A \& Liuzzi A. The relationship between active ghrelin levels and human obesity involves alterations in resting energy expenditure. Journal of Clinical Endocrinology and Metabolism 200489 936-939.

10 Cummings DE, Clement K, Purnell JQ, Vaisse C, Foster KE, Frayo RS, Schwartz MW, Basdevant A \& Weigle DS. Elevated plasma ghrelin levels in Prader Willi syndrome. Nature Medicine 20028 643-644.

11 DelParigi A, Tschop M, Heiman ML, Salbe AD, Vozarova B, Sell SM, Bunt JC \& Tataranni PA. High circulating ghrelin: a potential cause for hyperphagia and obesity in Prader-Willi syndrome. Journal of Clinical Endocrinology and Metabolism 200287 $5461-5464$

12 Haqq AM, Farooqi IS, O'Rahilly S, Stadler DD, Rosenfeld RG, Pratt KL, LaFranchi SH \& Purnell JQ. Serum ghrelin levels are inversely correlated with body mass index, age, and insulin concentrations in normal children and are markedly increased in Prader-Willi syndrome. Journal of Clinical Endocrinology and Metabolism $2003 \mathbf{8 8} 174-178$.

13 Tsolakis AV, Portela-Gomes GM, Stridsberg M, Grimelius L, Sundin A, Eriksson BK, Oberg KE \& Janson ET. Malignant gastric ghrelinoma with hyperghrelinemia. Journal of Clinical Endocrinology and Metabolism 200489 3739-3744.

14 Goldstone AP. Prader-Willi syndrome: advances in genetics, pathophysiology and treatment. Trends in Endocrinology and Metabolism $20041512-20$.

15 Shintani M, Ogawa Y, Ebihara K, Aizawa-Abe M, Miyanaga F, Takaya K, Hayashi T, Inoue G, Hosoda K, Kojima M, Kangawa K \& Nakao K. Ghrelin, an endogenous growth hormone secretagogue, is a novel orexigenic peptide that antagonizes leptin action through the activation of hypothalamic neuropeptide Y/Y1 receptor pathway. Diabetes $200150227-232$.

16 Wren AM, Seal LJ, Cohen MA, Brynes AE, Frost GS, Murphy KG, Dhillo WS, Ghatei MA \& Bloom SR. Ghrelin enhances appetite and increases food intake in humans. Journal of Clinical Endocrinology and Metabolism $2001865992-5995$.

17 Papotti M, Cassoni P, Volante M, Deghenghi R, Muccioli G \& Ghigo E. Ghrelin producing endocrine tumors of the stomach and intestine. Journal of Clinical Endocrinology and Metabolism $2001865052-5059$.

18 Corbetta S, Peracchi M, Cappiello V, Lania A, Lauri E, Vago L, Beck-Peccoz P \& Spada A. Circulating ghrelin levels in patients with pancreatic and gastrointestinal neuroendocrine tumors: identification of one pancreatic ghrelinoma. Journal of Clinical Endocrinology and Metabolism $2003 \mathbf{8 8}$ 3117-3120.

19 Broglio F, Gottero C, Van Koetsveld P, Prodam F, Destefanis S, Benso A, Gauna C, Hofland L, Arvat E, van der Lely AJ \& Ghigo E. Acetylcholine regulates ghrelin secretion in humans. Journal of Clinical Endocrinology and Metabolism $2004 \mathbf{8 9}$ 2429-2433.

20 Norrelund H, Hansen TK, Orskov H, Hosoda H, Kojima M, Kangawa K, Weeke J, Moller N, Christiansen JS \& Jorgensen JO. Ghrelin immunoreactivity in human plasma is suppressed by somatostatin. Clinical Endocrinology 200257 539-546.

21 Broglio F, Koetsveld Pv P, Benso A, Gottero C, Prodam F, Papotti M, Muccioli G, Gauna C, Hofland L, Deghenghi R, Arvat E, Van Der Lely AG \& Ghigo E. Ghrelin secretion is inhibited by either somatostatin or cortistatin in humans. Journal of Clinical Endocrinology and Metabolism 200287 4829-4832.

22 Newman CB, Melmed S, Snyder PJ, Young WF, Boyajy LD, Levy R, Stewart WN, Klibanski A, Molitch ME \& Gagel RF. Safety and efficacy of long-term octreotide therapy of acromegaly: results of a multicenter trial in 103 patients - a clinical research center study. Journal of Clinical Endocrinology and Metabolism $1995 \mathbf{8 0}$ 2768-2775 [Erratum in Journal of Clinical Endocrinology and Metabolism $1995 \mathbf{8 0} 3238]$.

23 Giustina A, Barkan A, Casanueva FF, Cavagnini F, Frohman L, Ho K, Veldhuis J. Wass J, Von Werder K \& Melmed S. Criteria for cure of acromegaly: a consensus statement. Journal of Clinical Endocrinology and Metabolism 200085 526-529.

24 Lewis I, Bauer W, Albert R, Chandramouli N, Pless J, Weckbecker G \& Bruns C. A novel somatostatin mimic with broad somatotropin release inhibitory factor receptor binding and superior therapeutic potential. Journal of Medical Chemistry $2003462334-2344$.

25 Bruns C, Lewis I, Briner U, Meno-Tetang G \& Weckbecker G. SOM230: a novel somatostatin peptidomimetic with broad somatotropin release inhibiting factor (SRIF) receptor binding and a unique antisecretory profile. European Journal of Endocrinology $2002146707-716$

26 Weckbecker G, Briner U, Lewis I \& Bruns C. SOM230: a new somatostatin peptidomimetic with potent inhibitory effects on the growth hormone/insulin-like growth factor-I axis in rats, primates, and dogs. Endocrinology $20021434123-4130$.

27 Schmid HA \& Schoeffter P. Functional activity of the multiligand analog SOM230 at human recombinant somatostatin receptor subtypes supports its usefulness in neuroendocrine tumors. Neuroendocrinology $2004 \mathbf{8 0} 47-50$.

28 Shimon I, Yan X, Taylor JE, Weiss MH, Culler MD \& Melmed S. Somatostatin receptor (SSTR) subtype-selective analogues differentially suppress in vitro growth hormone and prolactin in human pituitary adenomas. Novel potential therapy for functional pituitary tumors. Journal of Clinical Investigation 1997 $1002386-2392$.

29 Schwarting H, Koop H, Gellert G \& Arnold R. Effect of starvation on endocrine cells in the rat stomach. Regulatory Peptides 1986 $1433-39$.

30 Voyles NR, Awoke S, Wade A, Bhathena SJ, Smith SS \& Recant L. Starvation increases gastrointestinal somatostatin in normal and obese Zucker rats: a possible regulatory mechanism. Hormone and Metabolic Research $198214392-395$.

31 Roca B, Fernandez-Valencia R \& Arilla E. Effects of fasting and refeeding on somatostatin concentration and binding to cytosol from rabbit gastric mucosa. Gut $198829642-646$.

32 Mitra SW, Mezey E, Hunyady B, Chamberlain L, Hayes E, Foor F, Wang Y, Schonbrunn A \& Schaeffer JM. Colocalization of somatostatin receptor $\mathrm{sst}_{5}$ and insulin in rat pancreatic beta-cells. Endocrinology $19991403790-3796$.

33 Flanagan DE, Evans ML, Monsod TP, Rife F, Heptulla RA, Tamborlane WV \& Sherwin RS. The influence of insulin on circulating ghrelin. American Journal of Physiology Endocrinology and Metabolism 2003284 E313-E316.

34 Lippl F, Kircher F, Erdmann J, Allescher HD \& Schusdziarra V. Effect of GIP, GLP-1, insulin and gastrin on ghrelin release in the isolated rat stomach. Regulatory Peptides 2004119 93-98.

35 Kamegai J, Tamura H, Shimizu T, Ishii S, Sugihara H \& Oikawa S. Effects of insulin, leptin, and glucagon on ghrelin secretion from isolated perfused rat stomach. Regulatory Peptides 2004119 $77-81$.

36 Shimada M, Date Y, Mondal MS, Toshinai K, Shimbara T, Fukunaga K, Murakami N, Miyazato M, Kangawa K, Yoshimatsu H, Matsuo H \& Nakazato M. Somatostatin suppresses ghrelin secretion from the rat stomach. Biochemical Biophysical Research Communications 2003302 520-525.

37 Barkan AL, Dimaraki EV, Jessup SK, Symons KV, Ermolenko M \& Jaffe CA. Ghrelin secretion in humans is sexually dimorphic, suppressed by somatostatin, and not affected by the ambient growth hormone levels. Journal of Clinical Endocrinology and Metabolism $2003882180-2184$

38 Tan TM, Vanderpump M, Khoo B, Patterson M, Ghatei MA \& Goldstone AP. Somatostatin infusion lowers plasma ghrelin without reducing appetite in adults with Prader-Willi syndrome. Journal of Clinical Endocrinology and Metabolism $2004894162-4165$.

Received 4 February 2005

Accepted 18 February 2005 